\title{
How different cilia beat frequencies impact on Kupffer's vesicle fluid flow
}

\author{
R Rua ${ }^{1 *}$, A Guerrero², SS Lopes $^{1}$ \\ From First International Cilia in Development and Disease Scientific Conference (2012) \\ London, UK. 16-18 May 2012
}

Motile cilia need to be coordinated and ciliary beat frequency $(\mathrm{CBF})$ is characteristic of different types of cilia depending on their physiological function. In zebrafish, monociliated cells arise in the tailbud at the end of gastrulation in a transient spherical organ called Kupffer's vesicle (KV). Using zebrafish as a model, our group has been studying cilia length regulation and motility in wild-type (wt) and aei-/- mutant embryos. These mutants carry a premature stop codon in the deltaD gene. Recently, our group showed that Notch signaling was directly involved in the control of cilia length in the KV cells given that the aei-/- mutant present shorter cilia in KV cells. The goal of this project is the characterization of the CBF and beat patterns of aei-/- KV cilia vs. wt cilia. We did spectral analysis of individual cilia associated with high-speed digital videomicroscopy. By decomposing and comparing the obtained frequencies with Fourier Transform we have identified significant differences in KV cilia motility pattern between the wt and the aei-/- mutants. So far, we show that not only are the cilia shorter in the KV of aei-/mutants but also their motility pattern is different resulting in an overall destructive fluid flow.

http://www.cedoc.org

\section{Author details}

${ }^{1}$ Faculty of Medical Sciences, CEDOC, Portugal. IInstituto Gulbenkian Ciência, Portugal.

Published: 16 November 2012

Submit your next manuscript to BioMed Central and take full advantage of:

- Convenient online submission

- Thorough peer review

- No space constraints or color figure charges

- Immediate publication on acceptance

- Inclusion in PubMed, CAS, Scopus and Google Scholar

- Research which is freely available for redistribution
C Biomed Central 